\title{
GROWTH TRAITS AS AFFECTED BY CROSSING BETWEEN SINAI, GIMMIZAH AND SILVER MONTAZAH CHICKEN STRAINS
}

\author{
M. E. Soltan(1), S. A. Elsafty(2), Amal S. Zharan(1) and S. A. Farrag(1) \\ (1) Poultry and Fish production Department, Faculty of Agric., Menoufia University, Egypt. \\ (2) Poultry production Department, Faculty of Agriculture, Ain Shams University, Egypt.
}

Received: Oct. 31, 2021

Accepted: Nov. 4, 2021

\begin{abstract}
Aiming to study the effect of crossing between Sinai, Gimmizah and Silver Montazah chicken strains on growth performance of $F_{1}$ birds, a $3 \times 3$ partial diallel experiment was carried out in poultry research farm in Faculty of Agriculture - Shebin EIKom during the period between October 2018 and December 2020. Three purebreds and four crossbred genotypes were obtained. Growth traits including: body weight at different ages; daily weight gain (DG); growth rates (GR\%) have been recorded for all genotypes and the results summarized as follow: 1) Pure genotypes at the base generation showed significant differences in body weight at different ages, the same trend was also noticed at the F1 generation. 2) Gimmizah chicken strain was the heaviest birds at different ages (i.e., $B W h, \mathrm{BW}_{4}, \mathrm{BW}_{8}, \mathrm{BW}_{12}$ and $\mathrm{BW}_{16}$ ) at the base generation while Sinai strain was the lightest birds for all studied ages. 3) Crossing Sinai males to Gimmizah females resulted in heavier birds comparing with other crosses and reciprocals until 12 weeks of age. However, crossing Sinai females to Gimmizah males resulted the heavier birds across all four crosses at 16 weeks of age. Sex has a significant effect on body weight at all investigated ages, except body weight at hatch for all genotypes in the recent experiment. Interaction effect between strain and sex was not significant for body weight at different ages.

Gimmizah strain recorded the highest cumulative daily gain $(8.67 \mathrm{~g} / \mathrm{day})$ with no significant difference with the cross GS (Gimmizah males $\times$ Sinai females) which recorded $8.13 \mathrm{~g} /$ day (during the period from hatch to $16 \mathrm{wks}$ of age). At the F1 generation, differences between crosses, reciprocal crosses and pure strains were not significant according to ANOVA results, with one exception form 8-12wks of age there were significant differences in growth rate between the different genotypes. In conclusion, crossing Sinai chickens with Gimmizah and S. Montazah strains improved growth traits, and mating between Gimmizah males and Sinai females recommended for meat production purpose.
\end{abstract}

Key words: Growth traits, Sinai, Gimmizah, Montazah, Crossing effect

\section{INTRODUCTION}

Human population growing rapidly across globe including Egypt. Consequently, the need for different sources of protein increasing involving animal protein. Local chicken is considered one of the very important agricultural resources in Egypt and is characterized by many features that qualify it to be one of the pillars of the poultry industry in Egypt, such as good adaptation to the conditions of the
Egyptian environment and its capabilities (Khalil et al., 2018; El-Tahawy and Habashy 2021), in addition to the distinctive flavor, whether for meat or eggs, and we should work to improve the productivity of such breeds and strains maintaining it by taking care of it and applying effective improvement programs. Sinai chicken is one of the local breeds that is very distinguished in the characteristics of egg quality and heat stress tolerance, but egg production still needs to be improved. 
Crossbreeding is one of the important tools that play a major role in the improvement of the chicken's performance. Crossbreeding plans used to evaluate the ability of a population to combine with other populations (Jakubec, et al., 1987). One of the most known crossing designs is diallel cross (possible combinations between different populations, lines, strains or breeds). However, under experimental and field breeding conditions, not every crossbreeding effort produces desirable results. It is therefore important that an animal breeder knows what mating method to employ and what breeding goals to accomplish (Nwenya et al., 2017).

The current experiment aimed to study the effect of crossing between Sinai chickens and two other local strains traits including Gimmizah and Silver Montazah on growth traits.

\section{MATERIALS AND METHODS}

The present study was carried out between October 2018 to December 2020 in poultry research farm, Faculty of Agriculture, Menoufia University. The study was conducted to examine effects of crossing between Sinai Bedouin fowls and some other local chicken strains on growth traits. A $3 \times 3$ partial diallel experiment (Figure, 1) including three local strains (Sinai, Gimmizah and Silver Montazah chicken strains) and three

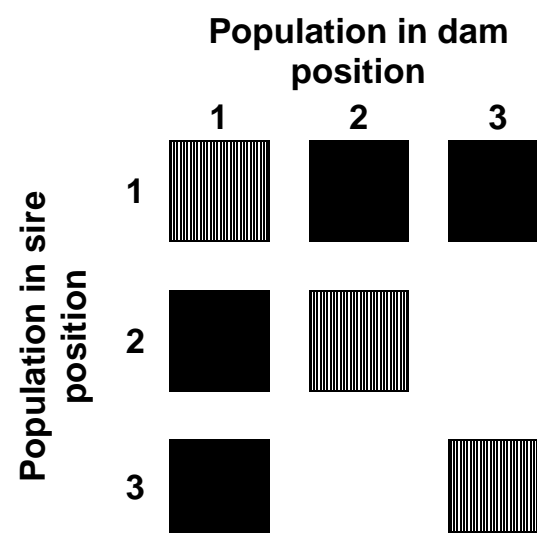

purebreds and four crossbred genotypes were obtained.

\section{Flock history:}

Sinai strain: Sinai chickens were characterized by laying fewer eggs which were smaller in weight. The first study was conducted by Arad et al. (1975) during the occupation of Sinai by Israel. Arad and Marder (1982) concluded that Sinai egg shell is thicker and stronger than that of the Leghorn. The result of Arad and Marder (1982) reported that Sinai breed was more resistant to the extreme conditions of desert environment. Soltan et al. (1985) gave an economical study for this breed. And he and his research team improved egg productions of this breed from 1985 till 2019 using different selection programs. Recently, egg number of this strain reached about 200 eggs per year. They indicated that means of egg number till 90 days of laying, egg weight, feed consumption (g/bird/day) and feed efficiency (g/g egg mass) were 20.7 eggs, $47.2 \mathrm{~g}, 85 \mathrm{~g}$ and $6.34 \mathrm{~g}$, respectively. Soltan and Ahmed (1990) showed that means of egg number, age at sexual maturity and egg weight of Sinai selected were 34.5 eggs, 186.6 days and $41.1 \mathrm{~g}$. respectively. Corresponding values were 31.6 eggs, 211.9 days and $42.0 \mathrm{~g}$ for the control line. Mahgoub (2002) reported that Sinai breed is well adapted to high environmental temperature.

Figure (1): Partial diallel mating design used in current study to obtain the F1 birds. 
Gimmizah strain: It is one of the local chickens that was developed as a result of crossing accompanied by selection of Dokki-4 and Plymouth Rock chickens by Prof. Dr. Taha Hussein Mahmoud and others. Gimmizah chicks are auto-sexing and are similar to Plymouth Rock chickens in terms of feather type. The egg production is $\mathbf{1 8 9}$ eggs, the average egg weight at the age of 12 months is $53 \mathrm{~g}$, and the average body weight for females at the end of the production period is $1830 \mathrm{~g}$. The fertility rate is $91 \%$, total hatchability is $86 \%$, and the production of chicks per mother is 145 chicks/52 weeks.

Sliver Montazah strain: Developed by crossing Rhode Island Red chicken and the Dokki-4 (Mahmoud et al., 1974). Silver Montazah chickens is predominantly grayish-white feather. The egg production is 200 eggs/year, the average egg weight at the age of 12 months is $56 \mathrm{~g}$, the average body weight of females at the end of the production period is $1730 \mathrm{~g}$, the fertility rate is $93 \%$, the total hatchability is $85-86 \%$, and the production of chicks per mother is $\mathbf{1 5 0}$ chicks/52wks. It is mainly an eggproducing synthetic strain.

\section{Experimental conditions:}

Chicks were brooded in floor brooder watered continuously and fed ad libitum during brooding period a diet containing $19.43 \%$ crude protein and $2916 \mathrm{kcal} / \mathrm{kg}$ ME. kcal, then at 16 weeks the ration was changed by a layer ration containing $17.10 \%$ crude protein and $2760 \mathrm{kcal} / \mathrm{kg}$ ME.

\section{First generation $\left(F_{1}\right)$ :}

The first generation included 7 genetic groups (Sinai strain, Gimmizah strain, Montazah strain, direct crosses between Sinai and either Gimmizah or $S$. Montazah (SG and SM) and their reciprocal crosses (GS and GM). The three parental strains of Sinai, Gimmizah and Silver Montazah were reared till 90 days of egg production (all traits where recorded) then were cross mated as planned.

\section{Flock management:}

All of the experimental parents and hatching chicks received the same managerial treatments. All trap nested egg produced from each breeding cage individually recorded according to the genetic group and collected daily for 7 days period. At hatch, the chick was pedigreed by wing banded and weighted. Brooders with the starting temperature of $32^{\circ} \mathrm{C}$ for the first week after hatching and then decreased $2-3^{\circ} \mathrm{C}$ each week thereafter. At eight week of age the chicks were sexed, weighed and moved to the rearing house.

\section{Studies traits:}

- Body weight at different ages: Individual body weight was recorded (to the nearest gram) at hatch (BW0) four (BW4) eight (BW8) twelve (BW12) and sixteen (BW16) weeks of age for each sex and line.

- Daily weight gain (DG): Interval daily weight gain (DG) during the periods from day old to 4 weeks (DG 0-4), from 4 to 8 week (DG 4-8), from 8 to 12 weeks (DG 8-12), from 12 to 16 weeks (DG 12-16), from day to 16 weeks (DG $0-16)$ and the cumulative daily weight gain were calculated for each line using the following formula:

Daily gain $($ gr/d $)=(w 2-w 1) /$ period Where:

W1 = Weight at the beginning the period

W2 = Weight at the end of the period

- Growth rates (GR\%): Interval growth rate (GR\%) during the period from day old to 4 weeks (GR 0-4), from 4 to 8 weeks (GR 4-8), from 8 to 12 weeks (GR 8-12), from 12 to 16 weeks (GR 12 16). The cumulative growth rate was calculated from day old to 16 weeks (GR0-16). All growth rates calculated according to the following equation: 


$$
\text { Growth rate } \%=\frac{W_{2}-W_{1}}{1 / 2\left(W_{1}+W_{2}\right)} \times 100
$$

W1 = weight at the beginning the period W2 = weight at the end of the period

\section{Statistical analysis:}

Collected data were entered and computerized and the analysis of variance done according the following model (two-way) using SPSS-IBM program v. 26.0 (2019). Significant differences among means were detected by Duncan test procedure implemented in the SPSS-IBM software (2019). Correlations between some of economic important traits were analyzed by person correlation equations implemented in SPSS-IBM program.

$Y_{i j k}=\mu+B_{i}+S_{j}+\left(B_{i} \times S_{j}\right)+e_{i j k}$

Where:

$Y_{i j k}=$ the value of the trait (observation)

$\mu=$ the general mean of the trait

$B_{i}=$ the fixed effect of $i^{\text {th }}$ strain on studied

trait (i= Sinai, Gimmizah, S. Montazah).

$S_{j}=$ the fixed effect of $j^{\text {th }}$ sex on studied trait $(j=$ male, female)

$\left(B_{i} \times S_{j}\right)=$ interaction effect of $i^{\text {th }}$ strain and $j^{\text {th }}$ sex.

$e_{i j k}=$ residual effect.

\section{RESULTS AND DISCUSSION}

\section{Body weight at different ages:}

Live body weights in the base and F1 generations for all investigated genotypes are shown in Table (1). Results showed that, pure genotypes at the base generation showed significant differences in body weight at different ages, the same trend was also noticed at the F1 generation. Gimmizah strain was the heaviest birds at different ages (i.e., BWh, BW4, BW8, BW12 and BW16) at the base generation as means of different strains tested by Duncan's test (implemented in IBM-SPSS program), Sinai strain was the lightest birds for all studied ages.

At the F1 generation, crossing between Sinai females and either Gimmizah or Montazah males didn't affected body weight at hatch significantly. On the other hand, crossing Sinai males to Gimmizah or Montazah females resulted in heavier birds than the pure Sinai birds at the same age (Table, 1), this may be attributed to the maternal effect on body weight at hatch. Significant differences between genetic groups in BWh has been recorded by Hasan (2019), in crossbreeding experiment included Alexandria, Gimmizah and Cobb chicken satins.

Body weight at 4 weeks of age didn't differed significantly between both 3 pure strains and 4 crosses, while, body weight at 8,12 and 16 weeks of age showed the same trend as in base generation (Sinai was the lightest birds and Gimmizah was the heaviest ones). This result is in contrast with those obtained by Hasan (2019), he reported significant variation in body weight at hatch, 4, 8 and 12 weeks of age between crossbred lines and purebreds. However, the differences were not significant, crossing Sinai females to Gimmizah males resulted the heavier birds across all four crosses in the current experiment. El-Tahawy and Habashy (2021) found that body weight at hatch, 4, 8 and 12 wks of age differed significantly according to line effect in a diallel cross experiment (included Sinai and Lohman brown purebreds).

Analysis of variance revealed that, sex have a significant effect on BW at all investigated ages, except BWh (Table, 1) for all genotypes. Current results are fully agreed with those obtained by Hasan (2019) regarding the statistical effect of sex on body weight at different ages except BWh. Interaction effect between strain and sex was not significant in the base generation, except on BW12 and BW16, while, in F1 generation all interaction effects were not significant for body weight at different ages. Hasan (2019) observed non-significant generation $\times$ line $\times$ sex interaction in his crossbreeding research between Alexandria, Gimmizah and Cobb chicken strains except for BW4. 
Table (1): Average body weight at different ages for different genotypes:

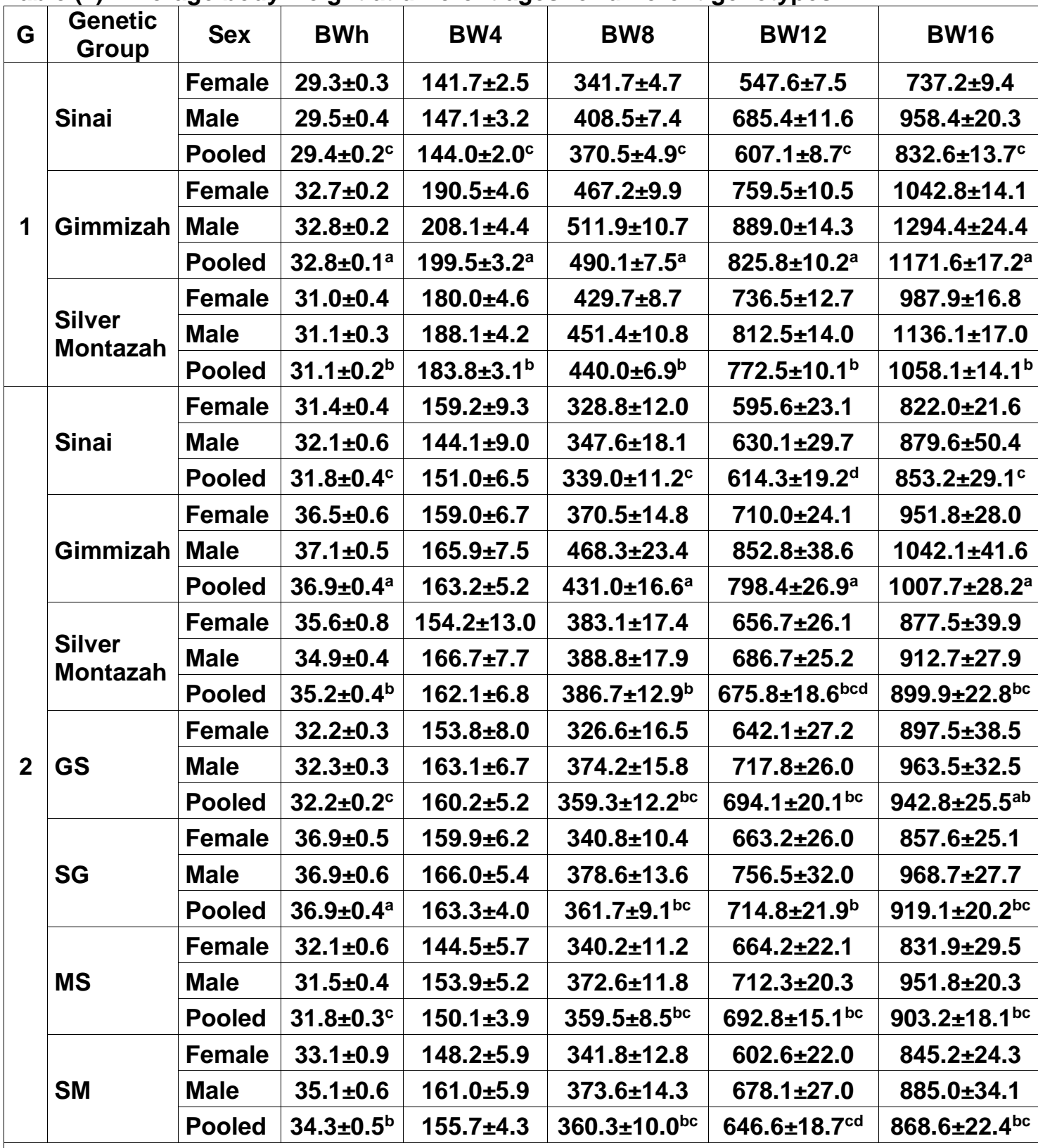

Analysis of variance results according to the source of variation (sex, strain and interaction)

\begin{tabular}{|c|c|c|c|c|c|c|}
\hline \multirow{3}{*}{1} & Strain & ** & ** & ** & ** & ** \\
\hline & Sex & NS & ** & ** & ** & ** \\
\hline & Strain $\times$ Sex & NS & NS & NS & * & * \\
\hline \multirow{3}{*}{2} & Strain & ** & NS & ** & ** & ** \\
\hline & Sex & NS & NS & ** & ** & ** \\
\hline & Strain $\times$ Sex & NS & NS & NS & NS & NS \\
\hline
\end{tabular}

BWh = body weight at hatch; BW4, 8, 12 and 16 = body weight at 4, 8, 12 and 16 weeks of age; G1 = first generation; $\mathbf{G 2}$ = second generation; GS, SG, MS, $\mathbf{S M}=$ crosses and reciprocal crosses between S-Sinai, G-Gimmizah, M-Silver Montazah strains with sires in the first position; G1 = first generation; $\mathbf{G 2}=$ Second generation; ${ }^{*}=$ highly significant differences $(\mathrm{P} \leq 0.01) ;{ }^{*}=$ significant differences ( $P \leq 0.05)$; NS = not significant (no significances) 
Findings from recent research regarding body weight at different studied ages are in harmony (within the range) with those reported previously (Iraqi et al., 2000; El-Amawy and Elham 2004; Amin 2008; Kosba and Abd ElHalim 2008; Taha and Abd El-Ghany 2013; Amin 2014; Soltan and Hussein 2017) for local Egyptian chickens with very few exceptions.

\section{Daily weight gain:}

Average daily weight gain for all studied genotypes at different periods of life are represented in Table 2. The highest daily gain was recorded by Gimmizah birds (males and females) during all life periods until 16 weeks of age, while the lowest gain by the day recorded by Sinai chickens. Males acquired body weight gain more than females at the same measuring period and the same strain. In the base generation daily weight gain showed significant differences $(P \leq 0.01)$ between all strains as well as between both sexes during all studied periods of life as shown in Table 2, in addition, interaction between strain and sex was significant in studied periods of life except during $h$ $4 w k s$ and 8-12wks of age. The pooled means of daily weight gain from hatch to $16 w k s$ of age were 10.17, 9.17 and 7.17 g/day for Gimmizah, S. Montazah and Sinai chickens, respectively (Table, 2).

In F1 generation, daily weight gain didn't differ significantly between different genotypes (parental, crosses and reciprocal crosses) or sexes during the first 4 weeks of age, then statistical differences were observed between both strains and sexes but not interaction between strain and sex effects until $12 w k s$ of age (i.e., during 4-8 and 8-12wks of age). Similar trend was detected by ElTahawy and Habashy (2021), they found highly significant differences due to line effect for daily weight gain in corresponding periods of life. Cumulatively, the daily weight gain from hatch until $16 \mathrm{wks}$ of age differed significantly ( $\mathrm{P} \leq 0.01)$ according to strain and sex effects but not interaction between both effects. These results are adequately similar to those reported by Iraqi et al., 2002 in crossbreeding report included two local strains (Mandarah and Matrouh), they didn't note significant differences between genetic groups in daily weight gain.

Gimmizah strain recorded the highest cumulative daily gain ( $8.67 \mathrm{~g} /$ day) with no significant difference with the cross GS (Gimmizah males $\times$ Sinai females) which recorded $8.13 \mathrm{~g} /$ day (during the period from hatch to $16 \mathrm{wks}$ of age) as represented in Table 2. The lowest daily gain during h-16wks period observed in Sinai pure strain as well as SM cross (Sinai males $\times$ S. Montazah females) 7.33 and $7.45 \mathrm{~g} /$ day, respectively. Other crosses don't show significant differences comparing with S. Montazah or Sinai pure strains (Table, 2). The estimates of body weight gain in different periods from recent study are lower than those found by other researchers worked on local chickens (EI-Nahal 2011; Iraqi et al., 2013; Taha and Abd El-Ghany 2013; Mahmoud and El-Full 2014; Hasan 2019), this could be due to the variations of genotypes, environmental conditions and design of the crossbreeding experiment.

\section{Growth rates (GR\%):}

Average growth rates for all studied genotypes at different periods of life are represented in Table 3. Results revealed that, at base generation (parental) Gimmizah and $S$. Montazah strains achieved the highest significant growth rate comparing with Sinai strain during all periods of life except at the period from 4-8wks of age Sinai chicken's growth rate was statistically higher than both Gimmizah and S. Montazah chickens (Table, 3). There were significant differences according to strain and sex effect in growth rates during studied periods of bird's life in the current research. In addition, interaction between strain and sex reported to be insignificant at discrete periods of live but it was highly significant during 
Growth traits as affected by crossing between sinai, gimmizah and silver

cumulative period from hatch till $16 \mathrm{wks}$ of age. Males always have the highest growth rate compared with females at all

periods of life, and sex effect on growth rate was highly significant (Table 3 ).

Table (2): Average daily weight gain at different periods of different genotypes:

\begin{tabular}{|c|c|c|c|c|c|c|c|}
\hline G & Strain & Sex & DG (h-4) & DG (4-8) & DG (8-12) & DG (12-16) & DG (h-16) \\
\hline \multirow{9}{*}{1} & \multirow{3}{*}{ Sinai } & Female & $4.01 \pm 0.09$ & $7.14 \pm 0.16$ & $7.35 \pm 0.22$ & $6.77 \pm 0.19$ & $6.32 \pm 0.09$ \\
\hline & & Male & $4.20 \pm 0.11$ & $9.34 \pm 0.23$ & $9.89 \pm 0.31$ & $9.75 \pm 0.50$ & $8.29 \pm 0.18$ \\
\hline & & Total & $4.09 \pm 0.07^{c}$ & $8.09 \pm 0.16^{c}$ & $8.45 \pm 0.21^{b}$ & $8.06 \pm 0.27^{c}$ & $7.17 \pm 0.12^{c}$ \\
\hline & \multirow{3}{*}{ Gimmizah } & Female & $5.64 \pm 0.16$ & $9.88 \pm 0.27$ & $10.44 \pm 0.28$ & $10.12 \pm 0.28$ & $9.02 \pm 0.13$ \\
\hline & & Male & $6.26 \pm 0.16$ & $10.85 \pm 0.32$ & $13.47 \pm 0.41$ & $14.48 \pm 0.45$ & $11.26 \pm 0.22$ \\
\hline & & Total & $5.95 \pm 0.12^{a}$ & $10.38 \pm 0.21^{a}$ & $11.99 \pm 0.28^{a}$ & $12.35 \pm 0.31^{\mathrm{a}}$ & $10.17 \pm 0.1^{a}$ \\
\hline & \multirow{3}{*}{$\begin{array}{c}\text { Silver } \\
\text { Montazah }\end{array}$} & Female & $5.32 \pm 0.17$ & $8.92 \pm 0.24$ & $10.96 \pm 0.41$ & $8.98 \pm 0.27$ & $8.54 \pm 0.15$ \\
\hline & & Male & $5.61 \pm 0.15$ & $9.40 \pm 0.37$ & $12.90 \pm 0.42$ & $11.56 \pm 0.36$ & $9.87 \pm 0.15$ \\
\hline & & Total & $5.46 \pm 0.11^{b}$ & $9.15 \pm 0.22^{b}$ & $11.88 \pm 0.31^{a}$ & $10.20 \pm 0.26^{b}$ & $9.17 \pm 0.13^{b}$ \\
\hline \multirow{21}{*}{2} & \multirow{3}{*}{ Sinai } & Female & $4.60 \pm 0.32$ & $6.02 \pm 0.33$ & $9.53 \pm 0.58$ & $8.08 \pm 0.66$ & $7.06 \pm 0.19$ \\
\hline & & Male & $4.04 \pm 0.30$ & $7.23 \pm 0.46$ & $10.09 \pm 0.55$ & $8.91 \pm 0.94$ & $7.57 \pm 0.45$ \\
\hline & & Total & $4.30 \pm 0.22$ & $6.68 \pm 0.30^{c}$ & $9.83 \pm 0.40^{b}$ & $8.53 \pm 0.59$ & $7.33 \pm 0.26^{c}$ \\
\hline & \multirow{3}{*}{ Gimmizah } & Female & $4.37 \pm 0.23$ & $7.56 \pm 0.47$ & $12.12 \pm 0.71$ & $8.64 \pm 0.73$ & $8.17 \pm 0.25$ \\
\hline & & Male & $4.60 \pm 0.27$ & $10.67 \pm 0.71$ & $13.73 \pm 0.78$ & $6.76 \pm 0.92$ & $8.97 \pm 0.37$ \\
\hline & & Total & $4.51 \pm 0.19$ & $9.46 \pm 0.51^{\mathrm{a}}$ & $13.12 \pm 0.56^{a}$ & $7.48 \pm 0.64$ & $8.67 \pm 0.25^{a}$ \\
\hline & \multirow{3}{*}{$\begin{array}{c}\text { Silver } \\
\text { Montazah }\end{array}$} & Female & $4.24 \pm 0.48$ & $8.17 \pm 0.52$ & $9.77 \pm 0.68$ & $7.88 \pm 0.68$ & $7.52 \pm 0.36$ \\
\hline & & Male & $4.72 \pm 0.27$ & $7.92 \pm 0.58$ & $10.64 \pm 0.54$ & $8.07 \pm 0.64$ & $7.84 \pm 0.25$ \\
\hline & & Total & $4.55 \pm 0.24$ & $8.01 \pm 0.41^{b}$ & $10.32 \pm 0.42^{b}$ & $8.00 \pm 0.47$ & $7.72 \pm 0.20^{\mathrm{bc}}$ \\
\hline & \multirow{3}{*}{ GS } & Female & $4.34 \pm 0.28$ & $6.17 \pm 0.44$ & $11.27 \pm 0.79$ & $9.11 \pm 0.81$ & $7.73 \pm 0.34$ \\
\hline & & Male & $4.67 \pm 0.24$ & $7.54 \pm 0.44$ & $12.27 \pm 0.51$ & $8.78 \pm 0.72$ & $8.31 \pm 0.29$ \\
\hline & & Total & $4.57 \pm 0.19$ & $7.11 \pm 0.34^{b c}$ & $11.96 \pm 0.43^{a}$ & $8.88 \pm 0.55$ & $8.13 \pm 0.23^{\mathrm{ab}}$ \\
\hline & \multirow{3}{*}{ SG } & Female & $4.37 \pm 0.21$ & $6.48 \pm 0.38$ & $11.51 \pm 0.81$ & $6.94 \pm 0.68$ & $7.33 \pm 0.22$ \\
\hline & & Male & $4.61 \pm 0.19$ & $7.59 \pm 0.44$ & $13.50 \pm 0.79$ & $7.58 \pm 0.64$ & $8.32 \pm 0.25$ \\
\hline & & Total & $4.50 \pm 0.14$ & $7.10 \pm 0.30^{\mathrm{bc}}$ & $12.61 \pm 0.58^{a}$ & $7.29 \pm 0.46$ & $7.88 \pm 0.18^{b c}$ \\
\hline & \multirow{3}{*}{ MS } & Female & $4.01 \pm 0.21$ & $6.99 \pm 0.38$ & $11.57 \pm 0.71$ & $5.99 \pm 0.96$ & $7.14 \pm 0.26$ \\
\hline & & Male & $4.37 \pm 0.19$ & $7.81 \pm 0.38$ & $12.13 \pm 0.65$ & $8.55 \pm 0.61$ & $8.22 \pm 0.18$ \\
\hline & & Total & $4.23 \pm 0.14$ & $7.48 \pm 0.28^{b c}$ & $11.90 \pm 0.48^{a}$ & $7.52 \pm 0.54$ & $7.78 \pm 0.16^{b c}$ \\
\hline & \multirow{3}{*}{ SM } & Female & $4.11 \pm 0.21$ & $6.91 \pm 0.38$ & $9.31 \pm 0.51$ & $8.66 \pm 0.56$ & $7.25 \pm 0.22$ \\
\hline & & Male & $4.50 \pm 0.21$ & $7.62 \pm 0.44$ & $10.88 \pm 0.65$ & $7.32 \pm 1.01$ & $7.59 \pm 0.30$ \\
\hline & & Total & $4.34 \pm 0.15$ & $7.33 \pm 0.30^{b c}$ & $10.23 \pm 0.44^{b}$ & $7.88 \pm 0.64$ & $7.45 \pm 0.20^{c}$ \\
\hline
\end{tabular}

Analysis of variance results according to the source of variation (sex, strain and interaction)

\begin{tabular}{|l|l|c|c|c|c|c|}
\hline \multirow{3}{*}{1} & Strain & $* *$ & $* *$ & $* *$ & $* *$ & $* *$ \\
\cline { 2 - 7 } & Sex & $* *$ & $* *$ & $* *$ & $* *$ & $* *$ \\
\cline { 2 - 7 } & Strain x Sex & NS & $* *$ & NS & $*$ & $*$ \\
\hline \multirow{3}{*}{2} & Strain & NS & $* *$ & $* *$ & NS & $* *$ \\
\cline { 2 - 6 } & Sex & NS & $* *$ & $* *$ & NS & $* *$ \\
\cline { 2 - 6 } & Strain $\times$ Sex & NS & NS & NS & NS & NS \\
\hline
\end{tabular}

GS, SG, MS, SM = crosses and reciprocal crosses between S-Sinai, G-Gimmizah, M-Silver Montazah strains with sires in the first position; G1 = first generation; G2 = Second generation; ** $=$ highly significant differences $(P \leq 0.01) ;{ }^{*}=$ significant differences $(P \leq 0.05)$; NS = not significant (no significances) 
M. E. Soltan, et al.,

Table (3): Average growth rates (\%) at different periods of different genotypes:

\begin{tabular}{|c|c|c|c|c|c|c|c|}
\hline G & Strain & Sex & GR (h-4) & GR (4-8) & GR (8-12) & GR (12-16) & GR (h-16) \\
\hline & \multirow{3}{*}{ Sinai } & Female & $130.2 \pm 1.2$ & $82.7 \pm 1.55$ & $46.1 \pm 1.13$ & $29.5 \pm 0.79$ & $184.4 \pm 0.2$ \\
\hline & & Male & $131.9 \pm 1.3$ & $94.0 \pm 1.58$ & $50.5 \pm 1.35$ & $32.4 \pm 1.58$ & $187.6 \pm 0.3$ \\
\hline & & Total & $130.9 \pm 0.9^{b}$ & $87.6 \pm 1.2^{\mathrm{a}}$ & $48.0 \pm 0.88^{c}$ & $30.8 \pm 0.8^{b}$ & $185.8 \pm 0.2^{b}$ \\
\hline & \multirow{3}{*}{ Gimmizah } & Female & $139.3 \pm 1.3$ & $84.1 \pm 1.46$ & $48.4 \pm 1.43$ & $31.4 \pm 0.73$ & $187.6 \pm 0.1$ \\
\hline \multirow[t]{4}{*}{. } & & Male & $143.7 \pm 1.2$ & $83.9 \pm 1.68$ & $54.1 \pm 1.56$ & $36.6 \pm 0.71$ & $189.8 \pm 0.2$ \\
\hline & & Total & $141.5 \pm 0.9^{a}$ & $84.0 \pm 1.1^{b}$ & $51.3 \pm 1.08^{b}$ & $34.1 \pm 0.5^{a}$ & $188.7 \pm 0.1^{\mathrm{a}}$ \\
\hline & \multirow{3}{*}{$\begin{array}{l}\text { Silver } \\
\text { Montazah }\end{array}$} & Female & $139.6 \pm 1.7$ & $82.1 \pm 1.82$ & $52.6 \pm 1.79$ & $29.1 \pm 0.72$ & $187.6 \pm 0.2$ \\
\hline & & Male & $142.3 \pm 1.1$ & $81.6 \pm 2.25$ & $57.4 \pm 1.76$ & $33.3 \pm 1.02$ & $189.2 \pm 0.1$ \\
\hline & & Total & $140.9 \pm 1.0^{a}$ & $81.9 \pm 1.4^{b}$ & $54.9 \pm 1.27^{a}$ & $31.1 \pm 0.6^{b}$ & $188.4 \pm 0.1^{\mathrm{a}}$ \\
\hline \multirow{21}{*}{2} & \multirow{3}{*}{ Sinai } & Female & $131.5 \pm 3.1$ & $69.7 \pm 3.87$ & $57.4 \pm 2.32$ & $32.5 \pm 2.78$ & $185.0 \pm 0.3$ \\
\hline & & Male & $124.0 \pm 2.9$ & $82.2 \pm 3.41$ & $57.9 \pm 2.04$ & $32.1 \pm 2.06$ & $185.0 \pm 0.7$ \\
\hline & & Total & $127.4 \pm 2.2$ & $76.4 \pm 2.69^{b}$ & $57.7 \pm 1.5^{b c}$ & $32.3 \pm 1.68^{a}$ & $185.0 \pm 0.4$ \\
\hline & \multirow{3}{*}{ Gimmizah } & Female & $123.4 \pm 2.5$ & $79.3 \pm 3.63$ & $62.7 \pm 3.16$ & $29.5 \pm 2.88$ & $184.8 \pm 0.5$ \\
\hline & & Male & $123.0 \pm 2.9$ & $92.1 \pm 3.54$ & $58.9 \pm 2.34$ & $20.8 \pm 3.05$ & $185.3 \pm 0.6$ \\
\hline & & Total & $123.2 \pm 2.0$ & $87.1 \pm 2.69^{a}$ & $60.4 \pm 1.8^{\mathrm{abc}}$ & $24.1 \pm 2.24^{b}$ & $185.1 \pm 0.4$ \\
\hline & \multirow{3}{*}{$\begin{array}{l}\text { Silver } \\
\text { Montazah }\end{array}$} & Female & $117.4 \pm 6.5$ & $87.2 \pm 5.70$ & $52.7 \pm 3.45$ & $28.1 \pm 1.98$ & $183.7 \pm 0.8$ \\
\hline & & Male & $127.1 \pm 3.1$ & $77.3 \pm 5.62$ & $56.7 \pm 3.29$ & $28.8 \pm 2.20$ & $184.7 \pm 0.5$ \\
\hline & & Total & $123.6 \pm 3.1$ & $80.9 \pm 4.15^{a b}$ & $55.3 \pm 2.43^{c}$ & $28.5 \pm 1.56^{a b}$ & $184.4 \pm 0.4$ \\
\hline & & Female & $127.2 \pm 3.3$ & $71.6 \pm 3.55$ & $65.4 \pm 3.93$ & $32.7 \pm 2.86$ & $185.4 \pm 0.6$ \\
\hline & & Male & $128.1 \pm 3.3$ & $77.7 \pm 2.99$ & $63.2 \pm 1.88$ & $29.5 \pm 2.13$ & $185.9 \pm 0.6$ \\
\hline & & Total & $127.8 \pm 2.5$ & $75.8 \pm 2.34^{b}$ & $63.9 \pm 1.7^{\mathrm{ab}}$ & $30.5 \pm 1.72^{\mathrm{ab}}$ & $185.7 \pm 0.5$ \\
\hline & \multirow{3}{*}{ SG } & Female & $123.1 \pm 2.3$ & $72.4 \pm 3.56$ & $63.0 \pm 3.48$ & $26.2 \pm 2.53$ & $183.1 \pm 0.5$ \\
\hline & & Male & $125.5 \pm 2.4$ & $77.2 \pm 3.07$ & $65.4 \pm 2.33$ & $26.1 \pm 2.53$ & $184.9 \pm 0.5$ \\
\hline & & Total & $124.4 \pm 1.6$ & $75.1 \pm 2.33^{b}$ & $64.3 \pm 2.0^{\mathrm{a}}$ & $26.2 \pm 1.78^{a b}$ & $184.1 \pm 0.4$ \\
\hline & \multirow{3}{*}{ MS } & Female & $124.2 \pm 3.4$ & $80.7 \pm 3.47$ & $63.7 \pm 2.98$ & $20.4 \pm 5.42$ & $182.8 \pm 2.3$ \\
\hline & & Male & $128.8 \pm 2.5$ & $80.6 \pm 4.96$ & $62.4 \pm 3.33$ & $29.6 \pm 2.13$ & $186.9 \pm 0.3$ \\
\hline & & Total & $126.9 \pm 2.0$ & $80.6 \pm 3.25^{a b}$ & $62.9 \pm 2.3^{\mathrm{ab}}$ & $25.9 \pm 2.56^{a b}$ & $185.2 \pm 0.9$ \\
\hline & \multirow{3}{*}{ SM } & Female & $125.2 \pm 2.7$ & $78.8 \pm 3.19$ & $55.1 \pm 2.16$ & $33.9 \pm 2.25$ & $184.6 \pm 0.6$ \\
\hline & & Male & $126.5 \pm 2.2$ & $79.2 \pm 2.97$ & $57.0 \pm 2.38$ & $26.0 \pm 3.62$ & $183.9 \pm 0.7$ \\
\hline & & Total & $126.0 \pm 1.7$ & $79.0 \pm 2.17^{\mathrm{ab}}$ & $56.2 \pm 1.6^{c}$ & $29.3 \pm 2.35^{\mathrm{ab}}$ & $184.2 \pm 0.5$ \\
\hline \multicolumn{8}{|c|}{$\begin{array}{l}\text { Analysis of variance results according to the source of variation (sex, strain and } \\
\text { interaction) }\end{array}$} \\
\hline \multirow{3}{*}{1} & \multicolumn{2}{|l|}{ Strain } & ** & ** & ** & ** & $* *$ \\
\hline & & ** & ** & $* *$ & ** & ** \\
\hline & \multicolumn{2}{|c|}{ Strain $\times$ Sex } & NS & $* *$ & NS & NS & $* *$ \\
\hline \multirow{3}{*}{2} & \multirow{2}{*}{\multicolumn{2}{|c|}{$\begin{array}{l}\text { Strain } \\
\text { Sex }\end{array}$}} & NS & NS & ** & NS & NS \\
\hline & & & NS & NS & NS & NS & $*$ \\
\hline & \multicolumn{2}{|c|}{ Strain $\times$ Sex } & NS & NS & NS & $*$ & NS \\
\hline \multicolumn{8}{|c|}{ 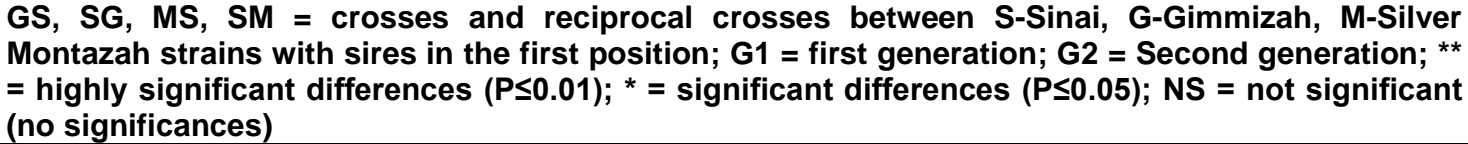 } \\
\hline
\end{tabular}


At the F1 generation, differences between crosses, reciprocal crosses and pure strains were not significant according to ANOVA results, with one exception form 8-12wks of age there were significant differences in growth rate between the different genotypes (Table 3). However, ANOVA results showed no significant variations between genotypes at the F1 generation, Duncan's multiple range test revealed some significances between genotypes under investigation (Table, 3). During the whole period (from hatch to 16wks of age) statistical analysis didn't reflect any significant differences between the different genotypes.

In agreement of recent base generation results but not for F1 generation Elnahal 2011 recorded statistical differences between different genetic groups in growth rate during first 4wks of life in his crossbreeding experiment. In addition, he found that during 4-8wks of age genetic groups differ significantly in growth rate. Moreover, recent study results adequately consisted with those found by Hasan (2019), except for growth rate during the first 4 wks of age. Moreover, estimates of growth rates during different periods of age under testing from current experiment falls within the previously reported values of local strains (Amin 2008; Amin et al., 2013; Taha et al., 2013; Abou El-Ghar 2014; Hasan 2019).

It could be concluded that, crossing Sinai chickens with the studied other strains (i.e., Gimmizah and S. Montazah) leads to improve growth traits in the obtained crosses and reciprocals. For meat production its recommended to mate Sinai females to Gimmizah males in order to achieve the highest value of growth traits resulted from crossing the studied local strains.

\section{REFERENCES}

Abou El-Ghar, R. Sh. (2014). Estimation of genetic and phenotypic parameters in 3 rd generation and backcrosses of some local strains of chicken. Egypt Poultry. Sci., 34 (2):521-535.

Amin, E. M. (2008). Effect of strain and sex among some local and foreign strain of chickens on productive traits (growth and egg production) under environmental condition of the newly reclaimed area. Egypt poultry. Sci., 28 (1): 351-366.

Amin, E. M. (2014). Genetic components and heterotic effect of growth traits in $3 \times 3$ diallel crossing experiment in chickens. Egypt poultry. Sci., 35 (3): 767-798.

Amin, E. M., M. A. Kosba, Amira, E. ElDlebshany and $M$. A. El-Nogomy (2013). Heterosis, maternal and direct additive effects for growth traits in the Alexandria chickens. Egypt poultry. Sci., 33 (4): 1033-1051.

Arad, Z. and J. Marder (1982 b). Comparison of the productive performances of the Sinai Bedouin fowl, the White Leghorn and their crossbred: Study under natural desert conditions. Bri. Poult. Sci. 23: 333 338.

Arad, Z., E. Moskovits and J. Marder (1975). A preliminary study of egg production and heat tolerance in a new breed of fowl (Laghorn $x$ Bedouin). Poult. Sci. 54: 780 - 783.

El-Amawy, and H. A. Elham (2004). Comparative study for the performance traits of established local lines and commercial hybrid broilers. M. Sc. Thesis, Fac. of Agric., Kafrelsheikh. Univ., Egypt.

El-Nahal, M. A. E. A. (2011). Effect of crossbreeding between some native strains of chicken on productive and reproductive traits. $M$. Sc. thesis. 
faculty of Agriculture, Alexandria university, Egypt.

El-Tahawy, W.S. and W.S. Habashy (2021). Genetic effects on growth and egg production traits in two-way crosses of Egyptian and commercial layer chickens. South African Journal of Animal Science 2021, 51 (No. 3): 349-354.

Hasan, O. A. M. (2019). Efficiency of crossing for growth traits and DNA molecular analysis in chicken. Faculty of Agriculture., (Poultry production), Alexandria university, Egypt.

IBM Corp. Released (2019). IBM SPSS Statistics for Windows, Version 26.0. Armonk, NY: IBM Corp.

Iraqi, M.M., A.F.M. El-Labban and M.H. Khalil (2000). Estimation of breeding values and their accuracies using multi-variates animal model analysis for growth traits in three local strains of chickens. Egyptian Poultry Science 20 (4): 981-1002.

Iraqi, M. M., M. H. Khalil and M. M. ElAttrouny (2013). Estimation of crossbreeding components for growth traits in crossing Golden Montazah with White Leghorn chickens. International conference: balnimalcon Tekirdag/ Turkey, 494-504.

Iraqi, M.M., M.S. Hanafi, M.H. Khalil, A.F.M. El-Labban and M. El-Sisy (2002). Genetic evaluation of growth traits in crossbreeding experiment involving two local strains of chicken using multi trait animal model. Livestock Research for Rural Development, 14 (Available at http://www.Irrd.org//rrd14/5/iraq145tm p.htm).

Jakubec, V., P. Komender, G. Nitter, D. Fewson and Z. Soukupova (1987). Crossbreeding in farm animals: I. Analysis of complete diallel experiments by means of three models with application to poultry. J. Anim. Breed. Genet. 104: 283-294

Khalil, M. H., A. A. Debes and M. K. Shebl (2018). Estimation of heterosis, combing ability and reciprocal effect for growth traits in chicken from a full diallel cross. International Journal of Research in Agricultural sciences volume 5, issue 6 issn (online): 23483997.

Kosba, B.M.A. and A. El-halim (2008). Evaluation of the Egyptian local strains of chickens. Egypt Poultry. Sci. 28 (4): 1239-1251.

Mahgoub, S. (2002). Study of some environmental factors affecting performance in chickens. M. Sc., Fac. Agric., Minufiya Univ., Egypt March, 1987 Flock, 1985.

Mahmoud, Bothaina, F. and Ensaf A. ElFull (2014). Crossbreeding components for daily gain and growth rate traits in crossing of rhode island red with gimmizah chickens. Egypt poultry. Sci., 34 (1): 151-163.

Mahmoud, T.H., I.F. Sayed and Y.H. Madkour (1974). The Silver Montazah a new breed of chickens. Egypt. J. agric. Res., 44: 97-105

NRC. Nutrient requirements of poultry (1994). 9th Revised edn. National Academy Press: Washington DC; Pp: 19-34.

Nwenya, J.M.I., E.P. Nwakpu, R.N. Nwose and K.P. Ogbuagu (2017). Performance and Heterosis of Indigenous Chicken Crossbreed (Naked Neck $\times$ Frizzled Feather) In the Humid Tropics. Journal of Poultry Research 14(2): 07-11.

Soltan, M. E and Eman A. Hussein (2017). Effect of different levels of tryptophan supplementation on growth performance and some blood constituents of Sinai Bedouin chickens. Egyptian J. Nutrition and feeds. 20 (3): 493-502. 
Soltan, M.E. and B. Ahmed (1990). Performance of selected Sinai fowl in comparison with Fayoumi and Baladi fowls standard Egyptian local breeds. 1- Egg production. World Rev. Anim. Prod. 25: 17 - 26.

Soltan, M.E., M. El-Nady, B. Ahmed and A. Abou Ashour (1985). Studies on the productive performance of Sinai
Bedouin fowl. Minufiya J. Agric. Res. 10: 2147 - 2168.

Taha, A.E. and F.A. Abd El-Ghany (2013). Improving Production Traits for ElSalam and Mandarah Chicken Strains by Crossing I- Estimation of Crossbreeding Effects for Growth Production Traits. Alexandria Journal of Veterinary Sciences, 39:18-30. 
M. E. Soltan, et al.,

تأثير الخلط بين سلالة سينا والجميزة والمنتزة الفضي علي صفات النمو

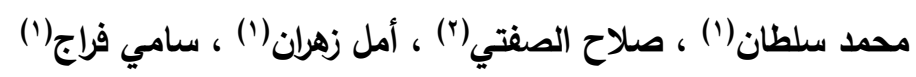

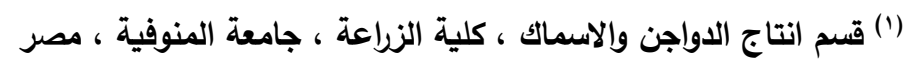

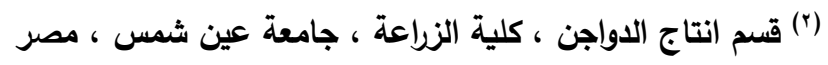

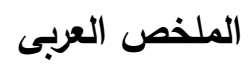

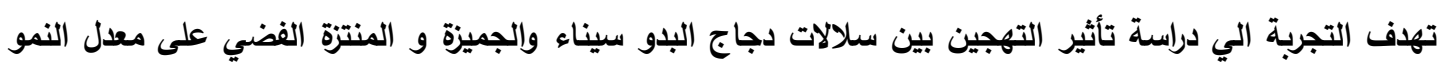

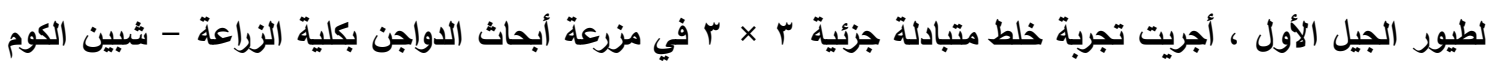

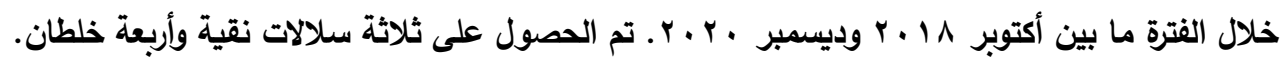

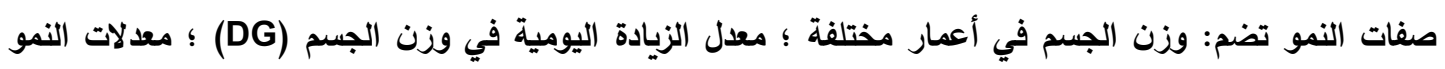
(GR)

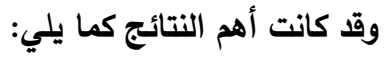
(1) وأظهرت الأنماط الجينية النقية في الجيل الأساسى اختلافات كبيرة في وزن الجسم في مختلف الأعمار، كما لوحظ

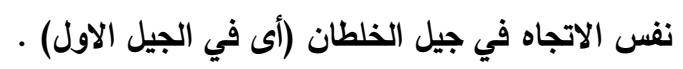

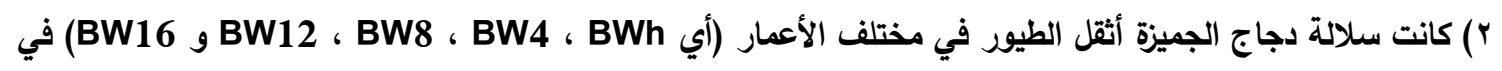

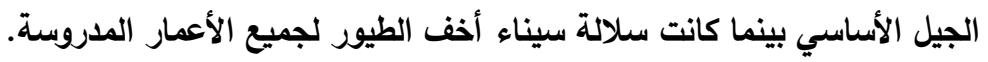

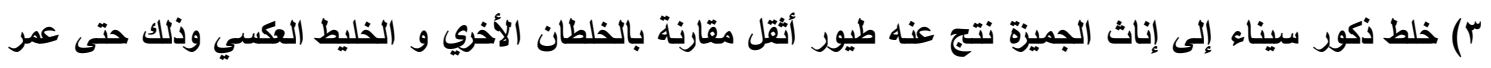

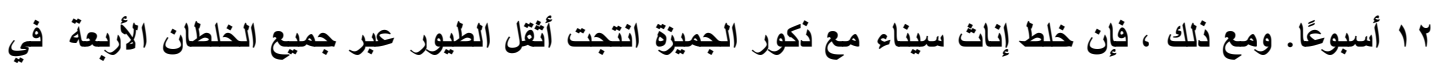

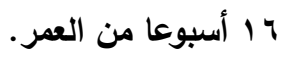

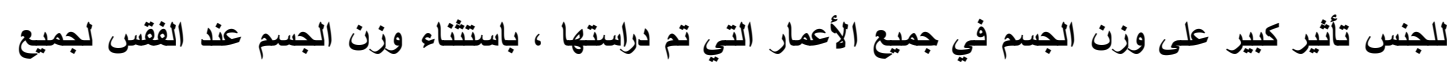

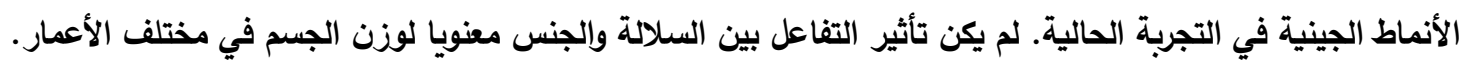

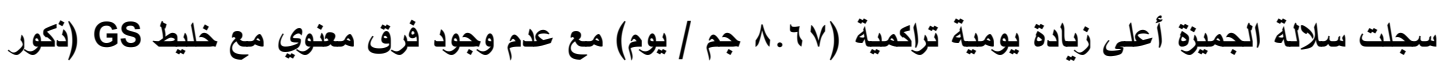

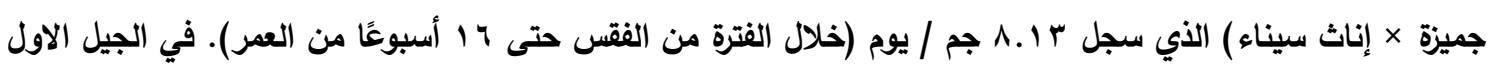

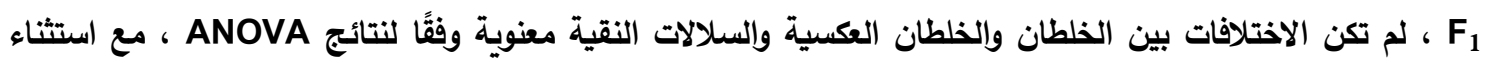

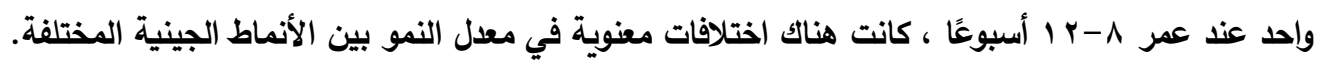

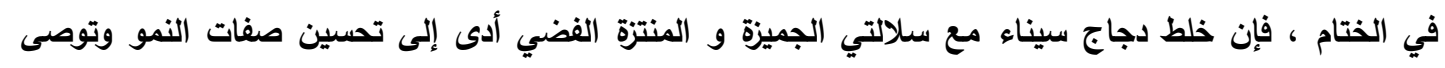

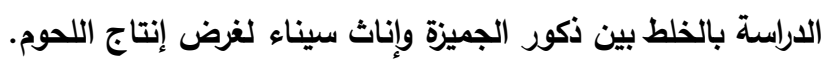

أسماء السادة المحكمين

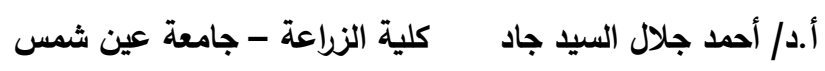

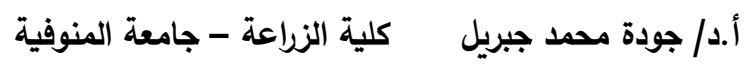

